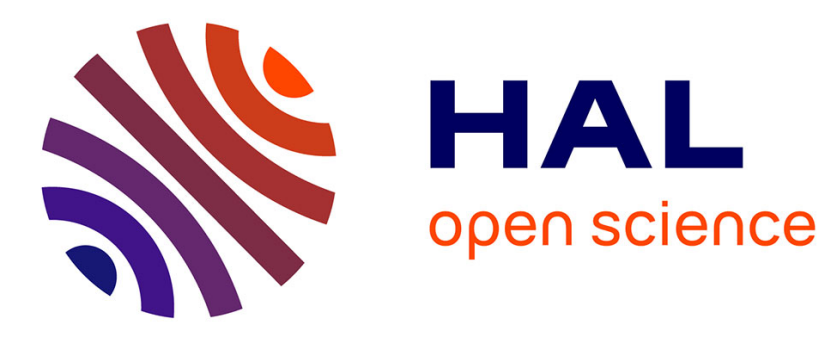

\title{
Lean and Green - Synergies, Differences, Limitations, and the Need for Six Sigma
}

Jose Arturo Garza-Reyes, Gabriela Winck Jacques, Ming K. Lim, Vikas Kumar, Luis Rocha-Lona

\section{- To cite this version:}

Jose Arturo Garza-Reyes, Gabriela Winck Jacques, Ming K. Lim, Vikas Kumar, Luis Rocha-Lona. Lean and Green - Synergies, Differences, Limitations, and the Need for Six Sigma. IFIP International Conference on Advances in Production Management Systems (APMS), Sep 2014, Ajaccio, France. pp.71-81, 10.1007/978-3-662-44736-9_9. hal-01387849

\section{HAL Id: hal-01387849 \\ https://inria.hal.science/hal-01387849}

Submitted on 26 Oct 2016

HAL is a multi-disciplinary open access archive for the deposit and dissemination of scientific research documents, whether they are published or not. The documents may come from teaching and research institutions in France or abroad, or from public or private research centers.
L'archive ouverte pluridisciplinaire HAL, est destinée au dépôt et à la diffusion de documents scientifiques de niveau recherche, publiés ou non, émanant des établissements d'enseignement et de recherche français ou étrangers, des laboratoires publics ou privés.

\section{(c)(1)}

Distributed under a Creative Commons Attribution| 4.0 International License 


\title{
Lean and Green - Synergies, Differences, Limitations, and the need for Six Sigma
}

\author{
Jose Arturo Garza-Reyes ${ }^{1}$, Gabriela Winck Jacques ${ }^{2}$, Ming K. Lim ${ }^{1}$, Vikas Kumar ${ }^{3}$, and Luis \\ Rocha-Lona $^{4}$ \\ ${ }^{1}$ Centre for Supply Chain Improvement, The University of Derby, Derby, UK \\ $\{\mathrm{J}$.Reyes, M. Lim\} @derby.ac.uk \\ ${ }^{2}$ Center for Exact and Technological Science, Univates, Lajeado, Brasil \\ gwjacques@hotmail. com \\ ${ }^{3}$ Bristol Business School, University of the West of England, Bristol, UK \\ Vikas.Kumar@uwe.ac.uk \\ ${ }^{4}$ Business School, National Polytechnic Institute of Mexico, Mexico City, Mexico \\ lrocha@ipn.mx
}

\begin{abstract}
Historically, profitability and efficiency objectives have been the prevailing interest for organisations. However, the move towards green operations has forced companies to seek alternatives to combine these with green objectives and initiatives. Green lean is the result of this combination. The purpose of this paper is to critically discuss the green lean approach and the potential benefits of integrating Six Sigma to enhance its effectiveness. The paper is based on a literature review that discusses the synergies and differences of lean and green, and its main limitations. Departing from the limitations identified, the paper then proposes Six Sigma, and specially its problem solving methodology DMAIC, as an approach that may help in overcoming the limitations of green lean. Thus, the paper conceptually proposes Green Lean Six Sigma. It intends to offer academics, researchers and practitioners interested in lean and green with some initial conceptual ideas regarding their possible integration with Six Sigma.
\end{abstract}

Keywords: DMAIC, Environment, Green, Lean, Six Sigma, Sustainability.

\section{Introduction}

Recently, with the rise of lean manufacturing and the increasing concerns for the environment, the market dynamic has changed. Historically, productivity has been the dominant concern for manufacturing organisations [1]. However, with the growth of quality management tools and increase in customers' demands for better prices, besides environmental regulations, companies have been forced to rethink how they manage their operations and processes. Since the 1950s lean manufacturing has been gaining fame in a wide range of industries all around the world, disseminating the concept of waste reduction [2]. On the other hand, green initiatives have been adopted as a requirement to comply with environmental regulations and meet market and social demands [3]. The combination of both seems logical, but two main questions arise from this: Can lean and green in fact work together? and Is their integration enough to effectively achieve positive productivity and green results at the same time?

As lean manufacturing aims at the elimination of waste in every area of production, design, supplier network and factory management [2], the combination of lean and green seems natural. Lean is a management approach that has helped companies to improve competitiveness and operational results [4]. Green, on the other hand, is an initiative that emerged from the concern for 
the environment and the rise of new regulations, norms, and standards on pollution prevention and control [3]. According to Dües et. al. [5], the combination of lean and green to form an integrated approach has only been discussed by a handful of experts and researchers. For example, Dües et. al. [5] carried out a study that aimed at exploring and evaluating, from a conceptual point of view, the existent relations between lean and the green concept. Similarly, Carvalho et al. [6] investigated the synergies and divergences between the lean and green paradigms, and their contribution towards a more sustainable and competitive supply chain. Also, Duarte and CruzMachado [7] examined how different business models can contribute to modelling a lean and green approach for an organisation. Mollenkopf et al. [8] investigated the relationship among green, lean, and global supply chain to provide a foundation for future researchers to build upon the company strategies. Hajmohammad et al. [9] tried to help understanding the roles of lean and supply management in relation to improving the firm's environmental performance. For this, Hajmohammad et al. [9] proposed and tested a conceptual model which suggests that the magnitude of environmental practices mediates the relationship between lean and supply management with environmental performance.

In general terms, these studies investigate the relationship between lean and green by highlighting the synergies and divergences between the two, their impact on supply chains' performance, and some of their theoretical implementation aspects when tried to be deployed seamlessly. Although the study presented in this paper also reviews and considers the synergies and divergences of lean and green, its main objective is to identify the possible limitations of the "green lean" paradigm as an integrated approach, and provide some research direction as to how these may be overcome. In light of this objective, the working methodology followed by this paper is based on a systematic review of the existent literature and exploring, analysing, and evaluating the information reviewed.

\section{Literature Review - What is Green Lean?}

Nowadays lean manufacturing is considered the most influential new paradigm in manufacturing [10] as empirical evidence suggests it improves the competitiveness of organisations [11] by reducing inventories and lead-times, and improving productivity and quality [12]. However, recently other concerns have emerged besides productivity, quality and cost. Today, sustainability has increasingly become important to organisations, as a result of concerns over environmental and social responsibilities [13]. These environmental concerns and the effectiveness of lean manufacturing contributed to the integration of the lean and green paradigms.

\subsection{Synergies of lean and green}

According to Mollenkopf et al. [8], lean companies, which deploy continuous improvement techniques, seem to be more likely to accept environmental innovations. As lean tends to emphasise waste reduction, it provides a better atmosphere to deploy green philosophies, initiatives and tools. In this scenario, the similarity between the two seems logical, waste reduction. However, green goes beyond waste reduction as it is also concerned with process efficiency, reduction of material consumption and recycling, and similarly as all the quality improvement approaches, one of its ultimate objectives is to improve customer's satisfaction. From this view, it is possible to identify several synergies between the lean and green concepts, these being: waste reduction, lead time reduction, and use of different approaches and techniques to manage people, organisations, and supply chain relations $[5,8]$.

According to the literature [5,6,7], waste reduction has different meanings in lean and green. For the lean management philosophy, waste refers to any activity that does not add value to the product while for the green concept waste is related to the wasteful consumption of water, energy or any natural resource [7]. Despite their difference, non-value added activities can also be considered part of wasting energy and natural resources. For example, unnecessary or excessive transportation of products and/or raw materials is not only one of the seven wastes defined by lean 
but also a waste of non-renewable natural resources. Thus, both practices aim for less transportation in order to save cost (lean) and reduce the consumption of natural resources and $\mathrm{CO}_{2}$ output (green) [6]. Another example is excessive inventory, which according to lean it is considered waste due to, in most of the cases, it increases lead time, prevents the rapid identification of problems, and discourages communication [14]. Excessive inventory also requires storage space and needs to be lighted, and sometimes heated or chilled, which from the environmental point of view may be considered a waste of energy if the lighting, heating and/or chilling is not done efficiently [15]. In this way, it is possible to relate all the seven lean wastes to those considered and defined by green initiatives. This indicates that lean can serve as a catalyst for green, facilitating companies the deployment of environmental policies and practices. In this way, a new strategy and management form can be defined through the compatibility between these two "cultures". However, there are still some areas in which lean and green cannot be combined as well as there are still some limitations when considering green lean as an integrated approach. The divergences between lean and green are discussed below.

\subsection{Divergences of lean and green}

Green initiatives can no longer be ignored by companies [5]. As it is discussed in the previous section, it is easier to deploy green initiatives in lean oriented companies, and the opposite is also valid. However, there are some objectives of both approaches that may not be possible to combine, for example: their focus, what are considered wastes, the customer, manufacturing strategies, and some practices adopted by organisations [5,8]. For this reason, despite the several synergies identified in the previous section, lean and green cannot perfectly be combined, they are concurrent and thus can effectively work together, but there are still some points that deserve attention when deploying both initiatives simultaneously.

According to Duarte and Cruz-Machado [7] the main difference between lean and green lies in how waste is defined, this divergence is also identified by Dües et al. [5]. As defined in the previous section, in lean, waste is any activity that does not add value to the customer while for green is the inefficient use of natural resources. Despite both meanings take the approach of working to improve processes at an operational level, lean focuses on workforce reduction, space reduction, increase capacity utilisation, higher system flexibility, and the use of standard components $[7,16]$. Whereas green ranges from practices like reduce, reuse and recycle (3Rs), rework, return, and remanufacture [7]. Another clear difference between lean and green is the type of customer [5]. Lean focus on cost and lead time reduction to satisfy customers [6] while in green, customers are more concerned as to whether the product that they are purchasing is helping them being more environmentally friendly $[5,8]$. Also, the green customer would not mind paying more for an environmental friendly product, which would not occur with lean customers.

So it is clear that lean and green are not completely compatible, there are still some areas in which they cannot be combined. However, those areas do not undermine or block the utilisation of lean and green simultaneously as an integrated management approach, contrariwise it gives the opportunity to improve both methods in a way that they can perfectly match. However, even as an integrated approach the green lean concept may still find some limitations that require attention, these are discussed in the following section.

\section{Limitations of Green Lean as an Integrated Approach}

There is little empirical evidence of the extent of adoption and effectiveness of green lean. However, based on the extensively documented success and expansion of lean into other industries different to manufacturing [10], and the fact that it is now accepted as a best practice for many organisations all around the world [17], it may be assumed that green lean will also be able to help organisations in achieving improvements that are not only financial and operational but also environmental oriented. 
Nevertheless, despite this assumption, the integrated green lean approach may suffer from the same limitations as the individual lean and green philosophies. In the case of lean, Salah et al. [18] think about it as a toolbox that is comprised of methods and tools that are directed toward the reduction of waste. These methods and tools were not all invented with this methodology, but they have been systematically used in a structured manner to form lean [18]. Limitations of the pure lean approach include the fact that (1) none of its methods or tools control and monitor a process using statistical data, (2) they do not scrutinise variations in processes, which are utilised for making decisions, and (3) there are no practices associated with the use of quality and advanced statistical/mathematical tools to identify further problems still remaining in processes after waste has been eliminated [19,20]. Thus, Assarlind et al. [21] suggest that lean organisations do not extensively utilise data in decision-making and that they should employ methodologies that promote a more scientific approach to quality. In this context, the lack of a data driven approach to process improvement makes lean less accurate and precise [22]. Also, despite lean being an operational approach that focuses on fulfilling customer's needs [2], it does not present a structured approach to control processes, solve problems, and/or systematically conduct improvement projects. The lack of a systematic approach to conduct improvements may also complicate the definition of wastes as previously discussed in Section 2.

On the other hand, in the case of green, although decision support and expert systems as well as design for environment (DfE) methods are available to support this approach, Chan et al. [23] comment that their application to solve green problems is limited. For this reason, unlike lean, green cannot be thought as a toolbox but as an initiative underpinned by the utilisation of a single tool, life cycle assessment. This will result in the green concept not being able to "lend" lean, if integrated with it, methods and tools that could help overcome the lean drawbacks previously discussed. Thus, the limitations of lean will be inherited by the green lean approach.

Following the same reasoning, an integrated green lean approach will not only confront the limitations of lean but also the limitations and challenges of the green approach. From the discussion of Nunes and Bennett [24] on environmental management systems (EMS) and green operations, it is possible to imply that the main limitations of green are not related to operational but strategic aspects. For example, Nunes and Bennett [24] suggest that although there is clear and strong reasons as to why organisations should implement green (i.e. through environmental management practices), it is still unclear to them how to make green decisions when a company faces a challenging strategic decision regarding where to make the investment when there are involved various possibilities (i.e. in facilities, manufacturing, logistics, marketing, process and product design, etc.). Another strategic challenge of green is how to implement its initiatives in a way in which they also meet corporate goals of profitability and other business requirements [24]. This is because in some cases, green activities will not return a profit from individual initiatives or be matched with corporate objectives.

Besides these strategic challenges, green can also present operational limitations. Joseph [25] comments that two of the most common include conversion expense and more expensive products. For example, it can be expensive for an organisation to go green initially as new energy saving equipment (i.e. solar panels) may need to be bought and installed. Unfortunately, cost reductions in energy savings gained by going green are not always enough to offset the initial capital conversion costs [25]. In addition, moving into the use of more environmentally friendly products can lead to more expensive products for consumers.

Similarly as with the inheritance of the lean limitations by the green lean approach, the limitations and challenges of the green concept will also be passed on to the integrated green lean approach, without lean being able to contribute to overcome some of them. For instance, in terms of prioritising strategic green investment decisions, lean lacks of a prioritisation approach [26] to support a decision of this type. In addition, since lean lacks of a project-based approach to improvement and thus a planning phase, it may not help in aligning the green lean initiatives to corporate goals of profitability as well as to other business requirements. This lack of a projectbased approach may also contribute to lean not being able to specifically focus and dedicate a project to identify the most cost effective and environmentally friendly equipment and raw 
material, which could offset and/or limit the negative impact on operational and product costs that these may have.

The individual limitations and challenges of lean and green, also inherited by the integrated green lean approach, and the lack of methods and/or tools from the "other" concept (i.e. lean or green) to overcome these, calls for the integration of additional methods and tools capable of contributing to the reduction or elimination of these challenges and limitations. These "other" methods and tools can come from Six Sigma.

\section{Green Lean Six Sigma?}

Initiated by Motorola in the 1980s, Six Sigma is now considered one of the most important developments to process improvement of the last decades [27]. Since then, Six Sigma has gained wide popularity among organisations worldwide, with most Fortune 500 companies using it [27] not only to improve their financial and operational performance but also customer satisfaction through the reduction of defective products and services. Six Sigma is a systematic, data and statistical driven problem solving and improvement methodology that intends to contain defects to 3.4 per every million opportunities, achieving with this lower costs and competitive operations. Garza-Reyes et al. [28] suggest the define, measure, analyse, improve, and control (DMAIC) cycle as one of the Six Sigma's distinctive and essential approaches to problem solving and process improvement. The DMAIC model indicates, step by step, how problems should be addressed, grouping quality and statistical tools, while establishing a standardised routine to solve problems [28].

The systematic, data and statistical driven characteristic of Six Sigma could complement the green lean approach and contribute in overcoming the limitations and challenges of this concept highlighted in Section 3. For example, the use of the DMAIC model could provide green lean with a more specific and holistic project based orientation to the implementation and achievement of green initiatives, which could then be continuously improved through kaizen. Thus, the Six Sigma's DMAIC methodology could be generalised as the umbrella under which green initiatives are implemented, managed, sustained and improved, see illustration in Figure 1. In this context, DMAIC will provide a unique characteristic of sequencing and linking lean and Six Sigma's methods and tools during the five stages of DMAIC when conducting a green project. In this way, lean and Six Sigma will contribute with the provision of methods and tools to help identify, define, prioritise, conduct, manage, achieve, sustain, and improve green initiatives.

In particular, the Define phase of DMAIC consists in identifying, prioritising and selecting the right project as well as clarifying the project's scope and defining goals [27,28]. Thus, at a strategic level, the Define phase of DMAIC could help an organisation to objectively prioritise green initiatives and investments in order to determine in which organisational activity/function (i.e. facilities, manufacturing, logistics, marketing, process, and product design) they should be deployed first, and/or in terms of which parameters (i.e. energy consumption, $\mathrm{CO}_{2}$ emissions, water consumption, etc.) should be targeted. Specific tools promoted by Six Sigma to achieve this may include Pareto analysis, project ranking matrix, project selection matrix, quality function deployment, project assessment matrix, Pareto priority index, cost benefit analysis, analytical hierarchy process (AHP), theory of constraints, etc. This scientific and data driven approach to defining and prioritising green initiatives would also ensure the selection of the right projects and investments, as well as it will aid in clarifying the objectives, scope, and resources of the green initiatives. This will also ensure their alignment with corporate goals.

The Measure stage of DMAIC consists in establishing reliable metrics to help monitoring key process characteristics, the scope of the parameters considered, and their performance in order to understand their progress towards the objectives [29]. At an operational level, the Measure phase of DMAIC will "force" an organisation, as an initial step, to identify the similarities, unify, and thus define the lean and green wastes (i.e. excessive $\mathrm{CO}_{2}$ emissions, water consumption, energy consumption, raw material consumption, inventory, transportation, etc.) into those that will be targeted for reduction/elimination. In addition, specific metrics (i.e. for electricity: KWh, green 
energy coefficient, energy reuse factor, carbon usage effectiveness, etc.; for $\mathrm{CO}_{2}$ emission tonns/week, etc.) for every waste will also need to be determined and agreed. Once that wastes and their metrics have been defined, current lean value stream studies can be conducted to identify the sources of waste and establish the scope of the parameters, as well as their current performance. Based on the DMAIC approach, the latest will be used to help monitoring progress towards the objectives established in the Define phase. This phase of DMAIC will start helping in overcoming the "lack of a data driven approach" limitation of green lean as quantitative data will be collected, analysed, and used as a comparative improvement base.

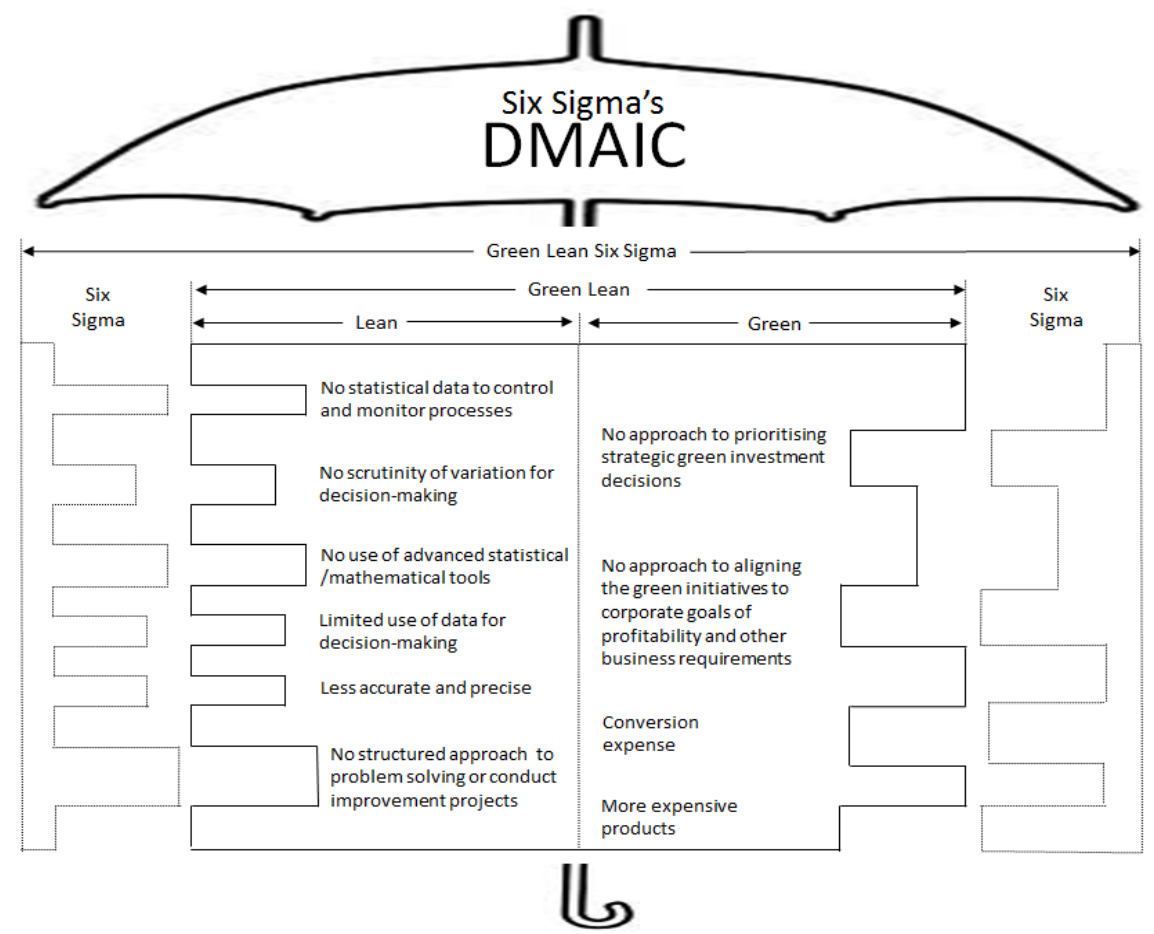

Fig. 1. Overcoming the green lean limitations through the integration of Six Sigma

The Analyse phase of DMAIC involves evaluating and identifying key causes and process determinants [29]. If integrated with green lean, this phase of DMAIC will contribute in determining the root causes of wastes in the parameters monitored. Six Sigma methods and tools based on inferential statistics such as scatter plots, analysis of variance (ANOVA), hypothesis testing, regression analysis, design of experiments (DOE), among others, will provide a quantitative-scientific base for the analysis. Other less quantitative, but still effective and systematic, methods that may include cause-and-effect diagrams and " 5 whys" could also be used in this stage to uncover wastes and the excessive (i.e. unnecessary) use of energy, water, raw material, $\mathrm{CO}_{2}$, etc.

The Improve phase of DMAIC consists of proposing, testing, and implementing creative solutions to eliminate the root causes of problems [27]. Methods and tools such as 5S, brainstorming, corrective action matrix, poka-yoke, among others, can be used to stimulate the development of solutions to reduce/eliminate the wastes identified in the Measure phase. In many cases, the solutions to tackle wastes could be as simple as, for example, installing occupancy sensors to turn lights off in offices when not needed, and reprogramming thermostats to avoid the unnecessary use of heating. Although determining the need to carry out improvements of this type may not require the systematic implementation and conduction of green initiatives, the Six Sigma's DMAIC approach will provide a platform to take decisions and courses of action based on real and scientific facts. Once embedded within the organisation's culture, this fact and 
scientific driven approach to decision-making will not only be used for green initiatives but also as part of the entire managerial approach of the organisation.

Finally, the Control phase involves setting the mechanisms for ongoing monitoring and institutionalising improvements [17]. After the objectives set in the Define stage have been achieved, methods such as Statistical Process Control (SPC) may help to monitor critical environmental parameters such as energy, water and raw material consumption, $\mathrm{CO}_{2}$ emissions, etc. In this case, SPC control charts will aid in statistically setting specification limits based on the maximum, average, and minimum consumption of the parameters monitored. This will allow differentiating the common and inherent variation in the consumption and use of these parameters from excessive uses due to assignable causes. In this context and based on the SPC methodology, investigations and corrective actions will be taken, specially, if the consumption of energy, water and raw material, or $\mathrm{CO}_{2}$ emissions exceed the maximum specified limit. SPC will also help to scrutinise and thus understand the degree and causes of variation in the consumption/use of these, which will help organisations in decision-making and assisting in the diagnosis of problems. The formal documentation of all the improvement actions taken and best practices, as suggested by the Control stage of DMAIC, will ensure that all employees perform the processes in a uniform manner, which will contribute to the reduction of variability in the consumptions of the green parameters considered.

\section{Conclusions}

Environmental sustainability is one of the strategic imperatives that nowadays must be aligned to the traditional organisational priorities of profitability and efficiency as well as customer satisfaction, quality, and responsiveness. The green lean approach has been proposed with the intention of achieving such alignment. However, conceptual and empirical studies regarding green lean are limited, and those conducted have focused on investigating aspects such as the synergies and divergences between the two, their impact on supply chains' performance, and some of their theoretical implementation issues. This paper has mainly focused on discussing the possible limitations of green lean as an integrated approach, which have been determined to be inherited from the individual limitations of every approach, and the fact that the "other" is unable to contribute in overcoming them. For this reason, the paper conceptually proposes and argues the integration of Six Sigma as a possible solution to address these limitations, complement the green lean approach, and enhance its effectiveness.

The paper has provided some initial discussion as to how integrating Six Sigma and creating a green lean Six Sigma unified approach could benefit green lean, but further research can be directed towards the proposal of a conceptual model for their integration, followed by its test and investigation into its empirical relevance to and effectiveness in industry.

\section{References}

1. Mohanty, R.P., Deshmukh, S.G.: Work Study Managing Green Productivity: A Case Study. Work Study. 48, 5, 165-169 (1999).

2. Chauhan, G., Singh, T.P.: Measuring Parameters of Lean Manufacturing Realization. Measuring Business Excellence. 16, 3, 57-71 (2012).

3. Digalwar, A.K., Tagalpallewar, A.R., Sunnapwar, V.K.: Green Manufacturing Performance Measures: An Empirical Investigation from Indian Manufacturing Industries. Measuring Business Excellence. 17, 4, 59-75 (2013).

4. Herron, C., Hicks, C.: The Transfer of Selected Lean Manufacturing Techniques from Japanese Automotive Manufacturing into General Manufacturing (UK) through Change Agents. Robotics and Computer-Integrated Manufacturing. 24, 4, 524-531 (2008).

5. Dües, C.M., Tan, K.H., Lim, M.: Green as the New Lean: How to Use Lean Practices as a Catalyst to Greening your Supply Chain. Journal of Cleaner Production. 40, 93-100 (2013).

6. Carvalho, H., Duarte, S., Cruz-Machado, V.: Lean, Agile, Resilient and Green: Divergences and Synergies. International Journal of Lean Six Sigma. 2, 2, 151-179 (2011). 
7. Duarte, S., Cruz-Machado, V.: Modelling Lean and Green: A Review from Business Models. International Journal of Lean Six Sigma, 4, 3, 228-250 (2013).

8. Mollenkopf, D., Stolze, H., Tate, W., Ueltschy, M.: Green, Lean, and Global Supply Chains. International Journal of Physical Distribution \& Logistics Management, 40, 1/2, 14-41 (2010).

9. Hajmohammad, S., Vachon, S., Klassen, R.D., Gavronski, I.: Lean Management and Supply Management: Their Role in Green Practices and Performance. Journal of Cleaner Production. 39, 312$320(2013)$.

10. Garza-Reyes, J.A., Parkar, H.S., Oraifige, I., Soriano-Meier, H. and Harmanto, D.: An EmpiricalExploratory Study of the Status of Lean Manufacturing in India. International Journal of Business Excellence. 5, 4, 395-412 (2012).

11. Abdul Wahab, A.N., Mukhtar, M., Sulaiman, R.: A Conceptual Model of Lean Manufacturing Dimensions. Procedia Technology. 11, 1292-1298 (2013).

12. Hines, P., Holweg, M. and Rich, N.: Learning to Evolve: A Review of Contemporary Lean Thinking, International Journal of Operations and Production Management. 24, 10, 994-1011 (2004).

13. Sezen, B., Çankaya, S.Y.: Effects of Green Manufacturing and Eco-Innovation on Sustainability Performance. Procedia - Social and Behavioral Sciences. 99, 6, 154-163 (2013).

14. Hines, P., Rich, N.: The Seven Value Stream Mapping Tools. International Journal of Operations and Production Management. 17, 1, 46-64 (1997).

15. Franchetti, M., Bedal, K., Ulloa, J., Grodek, S.: Lean and Green: Industrial Engineering Methods are Natural Stepping Stones to Green Engineering. Industrial Engineer. 41, 9, 24-29 (2009).

16. Pettersen, J.: Defining Lean Production: Some Conceptual and Practical Issues. The TQM Journal. 21, 2, 127-142, (2009).

17. Forrester, P.L., Shimizu, U.K., Soriano-Meier H., Garza-Reyes, J.A., Cruz Basso, L.F.: Lean Production, Market Share and Value Creation in the Agricultural Machinery Sector in Brazil. Journal of Manufacturing Technology Management. 21, 7, 853-871 (2010).

18. Salah, S., Rahim, A., Carretero, J.A.: The Integration of Six Sigma and Lean Management. International Journal of Lean Six Sigma. 1, 3, 249-274 (2010).

19. Devane, T.: Integrating Lean Six Sigma and High-Performance Organizations: Leading the Charge toward Dramatic, Rapid, and Sustainable Improvement. John Wiley \& Sons Inc., N.Y. (2004).

20. Lee, J.H., Garza-Reyes, J.A., Kumar, V., Rocha-Lona, L., Mishra, N.: A Comparative Study of the Implementation Status of Lean Six Sigma in South Korea and the UK. Advances in Sustainable and Competitive Manufacturing Systems, Lecture Notes in Mechanical Engineering, Springer, 1489-1502 (2013).

21. Assarlind, M., Gremyr, I., Bäckman, K.: Multi-faceted Views on a Lean Six Sigma Application. International Journal of Quality and Reliability Management. 29, 1, 21-30 (2012).

22. Hilton, R.J., Sohal, A.: A Conceptual Model for the Successful Deployment of Lean Six Sigma. International Journal of Quality and Reliability Management. 29, 1, 54-70 (2012).

23. Chan, C.C.S., Yu, K.M., Yung, K.L.: Green Manufacturing Using Integrated Decision Tools. The IEEE International Conference on Industrial Engineering and Engineering Management, Venetia, Italy, 7-10 December (2010).

24. Nunes, B., Bennett, D.: Green Operations Initiatives in the Automotive Industry: An Environmental Reports Analysis and Benchmarking Study. Benchmarking: An International Journal. 17, 3, 396-420 (2010).

25. Joseph, C.: The Disadvantages of Going Green for a Corporation. Demand Media. http://smallbusiness.chron.com/disadvantages-going-green-corporation-3318.html [April 14, 2014]

26. Bendell, T.: A Review and Comparison of Six Sigma and the Lean Organisations. The TQM Magazine $18,3,255-262$ (2006).

27. Garza-Reyes, J.A., Oraifige, I., Soriano-Meier, H., Harmanto, D., Rocha-Lona, L.: An Empirical Application of Six Sigma and DMAIC Methodology for Business Process Improvement. Proceedings of the 20th International Conference on Flexible Automation and Intelligent Manufacturing (FAIM), San Francisco, CA, US, 12-14 July (2010).

28. Garza-Reyes J.A., Flint, A., Kumar, V., Antony, J., Soriano-Meier, H.: A DMAIRC Approach to Lead Time Reduction in an Aerospace Engine Assembly Process. Journal of Manufacturing Technology Management. 25, 1, pp. 27-48 (2014).

29. Basu, R.: Implementing Quality - A Practical Guide to Tools and Techniques. Thomson Learning, London (2004). 